\title{
Glaucoma-induced changes in the ciliary ganglion
}

\author{
SHASHI KAPOOR AND M. SOOD \\ From the Department of Ophthalmology, Fawaharlal Institute of Postgraduate Medical Education and Research, \\ Pondicherry-6, India
}

The ciliary ganglion is a parasympathetic relay station, related to the innervation of the uvea. It is composed mainly of parasympathetic ganglion cells (Kurus, 1956). It has been shown to undergo degenerative changes after corneal cauterization (Bach, 1899; Bernheimer, 1897; Marina, 1899), iridectomy (Warwick, 1954), exenteration (Warwick, 1954), and evisceration (Tobari, 197I) but its relationship with glaucoma is still uncertain. Changes in intraocular pressure have been found on stimulation of the ciliary ganglion (Lele and Grimes, 1960; Schmerl and Steinberg, 1949). The aim of the present study was to find out what happens to the ciliary ganglion in experimental glaucoma.

\section{Material and methods}

Glaucoma was induced experimentally in one of the eyes of seven rhesus monkeys by inserting a hypodermic needle (26 gauge) into the anterior chamber through the temporal limbus under paraldehyde anaesthesia. The needle was connected to a saline reservoir which was elevated so as to maintain the intraocular pressure

Address for reprints: Dr Shashi Kapoor, Department of Ophthalmology, Jawaharlal Institute of Postgraduate Medical Education and Research, Pondicherry-6, India at $75 \mathrm{~mm}$ for 12 hours, after which the animals were killed. The globe, optic nerves, and ciliary ganglia were then examined histopathologically. Sections of $10 \mu \mathrm{m}$ thickness were stained with haematoxylin and eosin and methyl green pyronin.

\section{Results}

The ciliary ganglion comprises many ganglion cells. In a normal ciliary ganglion, each cell has a central nucleus, uniformly distributed Nissl granules in the cytoplasm, and a complete ring of glial cells around it (Figs $I$ and 2).

The histopathological changes seen in the ciliary ganglia after 12 hours of acute glaucoma were eccentric displacement or extrusion of the nucleus, and chromatolysis in the form of peripheral clumping or disappearance of the Nissl granules. No change was observed in the interstitial cells (Figs 3-5). The changes are summarized in the Table.

\section{Discussion}

The relationship of the ciliary ganglion to the innervation of the uvea has been demonstrated by the experiments of Tobari (1971) and Warwick

Table Ganglion cell changes in experimental acute glaucoma

\begin{tabular}{|c|c|c|c|c|c|c|c|c|}
\hline \multirow[t]{3}{*}{ Animal } & \multicolumn{4}{|l|}{ Nucleus } & \multicolumn{4}{|c|}{ Nissl granules } \\
\hline & \multirow{2}{*}{$\begin{array}{l}\text { Cells } \\
\text { examined }\end{array}$} & \multirow{2}{*}{ Normal } & \multicolumn{2}{|c|}{ Abnormal } & \multirow{2}{*}{$\begin{array}{l}\text { Cells } \\
\text { examined }\end{array}$} & \multirow{2}{*}{ Normal } & \multicolumn{2}{|c|}{ Abnormal } \\
\hline & & & No. & $(\%)$ & & & No. & $(\%)$ \\
\hline I & 1665 & I 328 & 337 & $20 \cdot 24$ & 478 & 56 & 422 & $88 \cdot 28$ \\
\hline 2 & 1727 & I369 & $35^{8}$ & $20 \cdot 73$ & $45^{2}$ & 43 & 409 & $90 \cdot 48$ \\
\hline 3 & I 598 & 1274 & 324 & $20 \cdot 27$ & 413 & 44 & 369 & $89 \cdot 33$ \\
\hline 4 & 1635 & 1288 & 347 & $21 \cdot 22$ & 449 & 53 & 396 & $88 \cdot 20$ \\
\hline 5 & I 874 & 1509 & 365 & $19 \cdot 48$ & 489 & 72 & 417 & $85 \cdot 27$ \\
\hline 6 & I 688 & $135^{\circ}$ & 338 & $20 \cdot 04$ & 465 & 62 & 403 & $86 \cdot 66$ \\
\hline 7 & 1473 & 1185 & 288 & 19.55 & 376 & 41 & 335 & $89 \cdot 08$ \\
\hline Total & 11660 & $93 \circ 3$ & 2357 & $\begin{array}{l}20 \cdot 2 \\
\text { (average) }\end{array}$ & 3122 & 371 & 2751 & $\begin{array}{l}88 \cdot 2 \\
\text { (average) }\end{array}$ \\
\hline
\end{tabular}




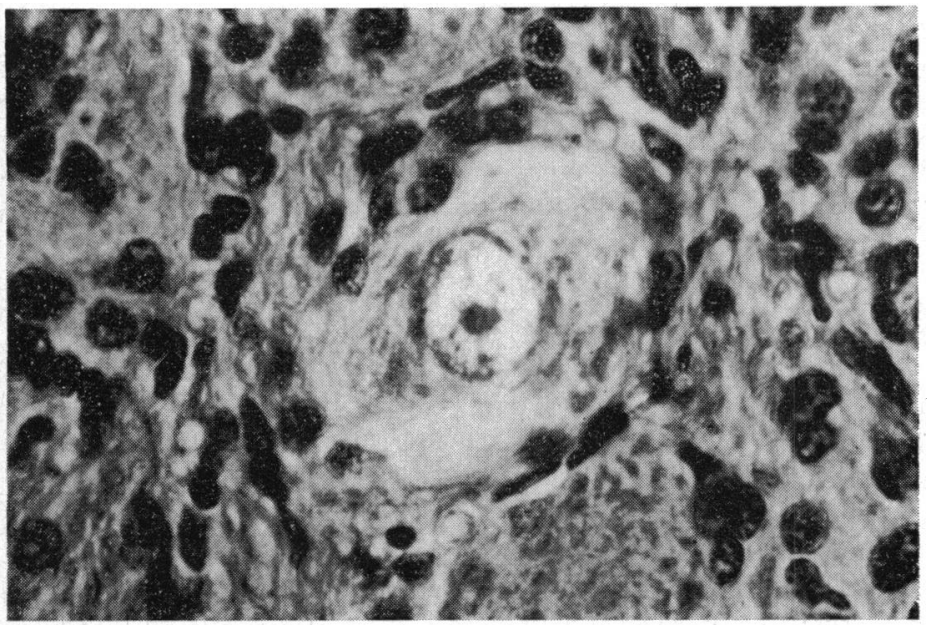

FIG. I Normal ganglion cell with central nucleus and a ring of glial cells. Haematoxylin and eosin. $\times 500$

(1954). Armaly (1968) observed smooth muscle atrophy in the iris and the ciliary body after resection of the ciliary ganglion. The changes observed in the ciliary ganglion after 12 hours of experimental glaucoma were similar to those seen after the experiments of Tobari (1971) and Warwick (1954). This could indicate involvement of uveal innervation directly or as a consequence of smooth muscle atrophy of the uveal tract, secondary to the rise in intraocular pressure.

Experimental glaucoma has been shown to initiate (Dieter, 1940; Lele and Grimes, 1960; Tower, 1940), increase, or modify the already existing electrical discharges in the ciliary nerves (Belmonte, Simon, and Gallego, 1971; Perkins, 1961; von Sallmann, Fuortes, Macri, and Grimes, 1958). These discharges may originate from the innervation of the trabeculum (Belmonte and others,
197I), detected by Chapman and Spelsberg (1963), Feeney (1962), Fine (1964), Holland, von Sallmann, and Collins (1956, 1957), and Vrabec (1954). These $\vec{\theta}$ electrical discharges may be appearing not only in ov the ciliary nerves but also in the ciliary ganglion, which is their point of origin. The damage inflicted on the ciliary ganglion in experimental glaucoma could be a part of the ascending process of degeneration seen in ciliary nerves after glaucoma (Matsuyama, 1969) or a result of the electrical discharges which follow a rise in intraocular pressure.

The degenerative changes in the ciliary ganglion make their appearance as early as 12 hours after the induction of glaucoma, so that they cannot be due to an ascending process of degeneration in the ciliary nerves. Such a change, if due to Wallerian degeneration, would not be visible until 14 days

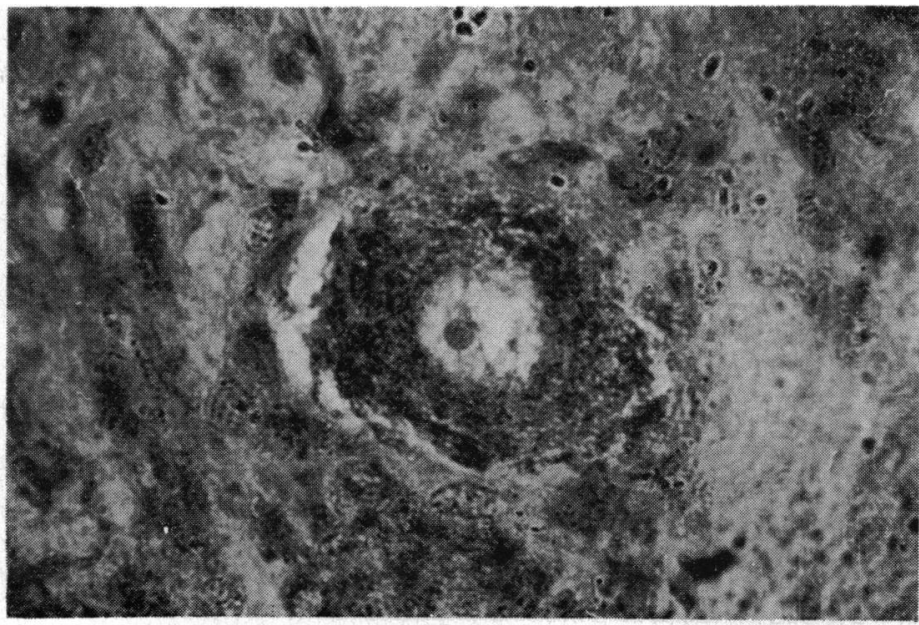

FIG. 2 Normal ganglion cell with Nissl granules uniformly distributed and a central nucleus. Methyl green pyronin. $\times 400$ 


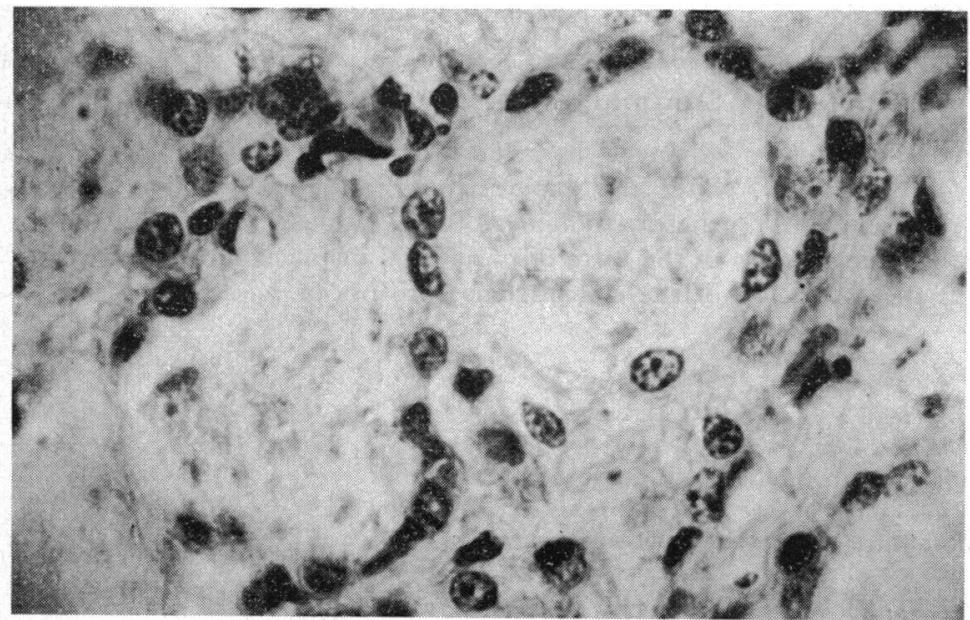

FIG. 3 Ganglion cell without any nucleus after $12 \mathrm{hr}$ of glaucoma.

Haematoxylin and eosin. $\times 500$

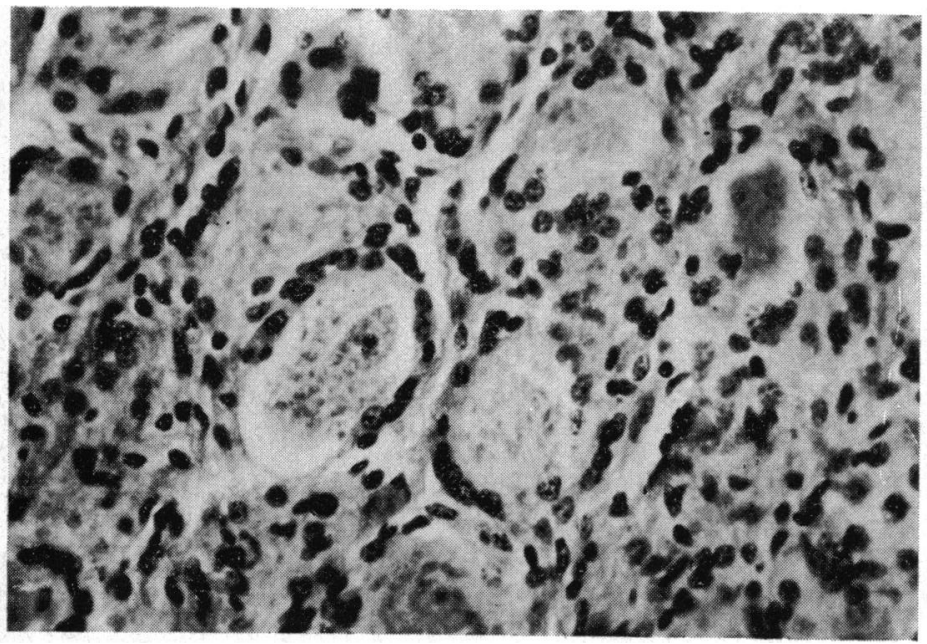

FIG. 4 Ganglion cells with peripheral displacement and loss of nucleus. Haematoxylin and eosin. $\times 100$

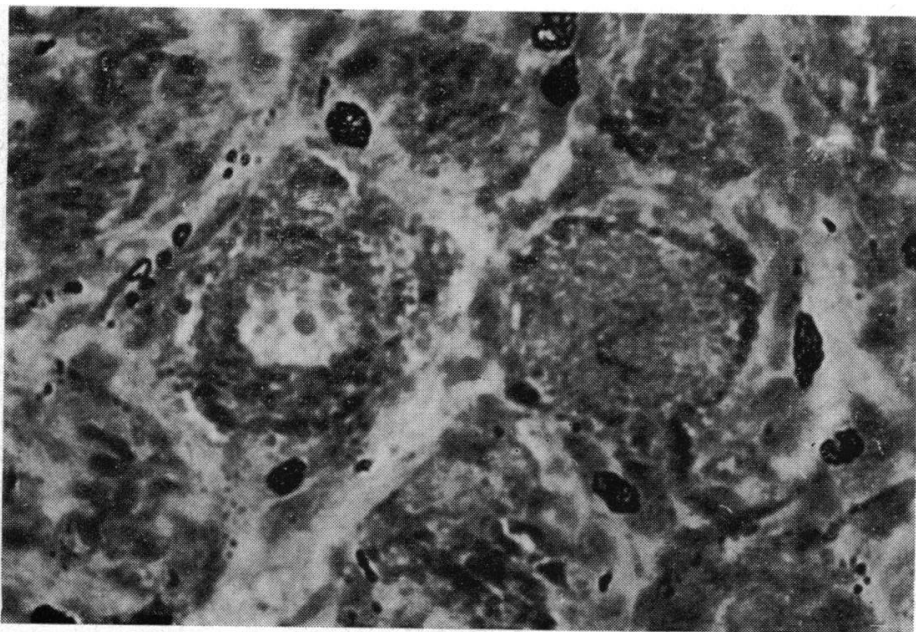

FIG. 5 A normal and an involved ganglion cell. Involved cell is without nucleus and the Nissl granules are placed in periphery. Methyl green pyronin. $\times 400$ 
(Tobari, 1971) after the onset of glaucoma. Thus electrical activity is likely to be the only explanation of such an early change in the ganglion cells. This is similar to the permanent damage inflicted on a muscle spindle by the receptor overload after repeated exposures to an excessive stimulus (Matthews, I93I).

This casts doubt on the hypothesis of Weinstein (1957) that iridectomy acts by causing degeneration in the ciliary ganglion. Also, changes in the ciliary ganglion may be responsible for the early loss of pupillary reaction in acute glaucoma.

\section{Summary}

Changes in ciliary ganglion cells are described after the experimental induction of glaucoma in rhesus monkeys. They appear within 12 hours in the form of peripheral displacement or extrusion of the cell nucleus and loss of Nissl granules.

\section{References}

ARMaly, M. F. (1968) Trans. Amer. ophthal. Soc., 66, 475

васн (1899) v. Graefes Arch. Ophthal., 47, 339 (cited by Duke-Elder and Wybar, r96r)

Belmonte, G., Simon, J., and gallego, A. (1971) Exp. Eye Res., 12, 342

BERNHEIMER (1897) v. Graefes Arch. Ophthal., 44, 481 (cited by Duke-Elder and Wybar, 196r)

CHAPMAN, C. B., and SPELSBERG, w. W. (1963) Exp. Eye Res., 2, I 30

DIETER, w. (1940) Ber. dtsch. ophthal. Ges., 53, 53

DUKE-ELDER, S., and WYBAR, K. L. (196r) 'System of Ophthalmology', vol. 2, p. 859. Kimpton, London FEENEY, L. (1962) Invest. Ophthal., 1,462

FINE, B. S. (1964) Ibid., 3, 609

holland, B. G., von Sallmann, L., and collins, E. M. (1956) Amer. F. Ophthal., 42, 148

$$
\longrightarrow \text {, and (1957) Ibid., 44, } 206
$$

KURUS, E. (1956) Klin. Mbl. Augenheilk., 129, 183

LELE, P. P., and GRIMES, P. (1960) Exp. Neurol., 2, 199

MARINA (I 899) Dtsch. Z. Nervenheilk, 14, 356 (cited by Duke-Elder and Wybar, 1961)

MATSUYAMA, M. (1969) Folia ophthal. jap., 20, 695

matthews, B. H. (1931) भ. Physiol. (Lond.), 7r, 64

PERKINS, E. S. (196I) Exp. Eye Res., 1, 160

SCHMERL, E., and STEINBERG, B. (1949) Ibid., 32, 947

TOBARI, I. (1971) Acta Soc. Ophthal. jap., 75, 1446

TOWER, S. S. (1940) $\mathcal{Y}$. Neurophysiol., 3, 486

VON SAllmanN, L., FUORTES, M. G. F., MACRI, F. J., and GRIMES, P. (1958) Amer. Y. Ophthal., 45 (Pt. II), 2 I I

VRABEC, F. (1954) Ophthalmologica (Basel), 128, 359

WARWICK, R. (1954) F. Anat. (Lond.), 88, 71

WEINSTEIN, P. (I957) Öst. Ophthal. Ges., 3rd annual meeting, pp 79-82 